\title{
MICROBIAL RESPIRATION AND CHEMICAL COMPOSITION OF DIFFERENT SEDIMENT FRACTIONS IN WATERBODIES OF THE UPPER PARANÁ RIVER FLOODPLAIN, BRAZIL
}

\author{
THOMAZ, S. M., ${ }^{1}$ PEREIRA, G. ${ }^{2}$ and PAGIORO, T. A. ${ }^{1}$ \\ ${ }^{1}$ Departamento de Biologia, Nupélia, Universidade de Maringá, Av. Colombo, 5790, CEP 87020-900, \\ Maringá, PR, Brazil \\ ${ }^{2}$ Programa de Pós-graduação em Ecologia de Ambientes Aquáticos Continentais, Departamento de Biologia, \\ Nupélia, Universidade de Maringá, Av. Colombo, 5790, CEP 87020-900, Maringá, PR, Brazil \\ Correspondence to: Sidinei Magela Thomaz, Departamento de Biologia, Nupélia, Universidade de Maringá, \\ Av. Colombo, 5790, CEP 87020-900, Maringá, PR, Brazil, e-mail: smthomaz@ nupelia.uem.br \\ Received January 21, 2000 - Accepted March 8, 2000 - Distributed May 31, 2001
}

(With 4 figures)

\begin{abstract}
Four size fractions of the sediment of six environments of the upper Paraná River floodplain were analyzed for carbon, nitrogen, and phosphorus contents and microbial respiration (oxygen consumption). Particle size did not affect nitrogen and phosphorus content or microbial activity, but did affect carbon content $(\mathrm{F}=4.274, \mathrm{df}=3 ; 20, \mathrm{p}=0.020)$. The carbon concentration of ultra-fine particles was significantly lower than that of other sizes of sediment particles. Microbial respiration values were well predicted by sediment chemical composition, as shown by multiple regression (microbial respiration $=-0.39-0.210 \mathrm{C}+0.108 \mathrm{~N}+0.796 \mathrm{P} ; \mathrm{F}=7.0495, \mathrm{p}=0.0022$ ). However, phosphorus was the element which best explained the microbial respiration (partial coefficient $=0.796, p=0.0039$, $\mathrm{n}=23$ ). Considering that i) phosphorus was the best predictor of microbial respiration; ii) phosphorus is trapped in the series of reservoirs located upstream from the section of the floodplain studied; and iii) microbial respiration is a measure of decomposition rates and nutrient cycling, we hypothesize that the long-term accumulation of litter detritus and reduction of nutrient cycling in environments of the upper Paraná River floodplain are probable impacts of this decrease in phosphorus caused by the upstream reservoirs.
\end{abstract}

Key words: microbial respiration, nutrient cycling, floodplain, sediment fractions, Paraná River.

\section{RESUMO}

\section{Respiração microbiana e composição química de diferentes frações do sedimento de ambientes aquáticos da planície de inundação do alto Rio Paraná, Brasil}

Quatro frações do sedimento, de tamanhos diferentes, de seis ambientes da planície de inundação do alto Rio Paraná foram analisadas quanto ao teor de carbono, nitrogênio e fósforo e quanto à respiração microbiana (consumo de oxigênio). O tamanho das partículas não afetou o conteúdo de nitrogênio e fósforo ou a atividade microbiana, influenciando apenas o conteúdo de carbono $(\mathrm{F}=4,274$, df $=$ $3 ; 20, p=0,020)$. As concentrações de carbono das partículas ultrafinas foram significativamente menores que as concentrações das partículas de outros tamanhos. Os valores da respiração microbiana refletiram a composição química do sedimento, como demonstrado na análise de regressão múltipla. (respiração microbiana $=-0,39-0,210 \mathrm{C}+0,108 \mathrm{~N}+0,796 \mathrm{P} ; \mathrm{F}=7,0495, \mathrm{p}=0,0022)$. Entretanto, o fósforo foi o elemento que melhor explicou a respiração microbiana (coeficiente parcial $=0,796$, $\mathrm{p}=0,0039, \mathrm{n}=23$ ). Considerando que i) o fósforo foi o melhor preditor da respiração microbiana; ii) o fósforo é retido em uma série de reservatórios localizados a montante da planície de inundação 
estudada; e iii) a respiração microbiana é uma medida das taxas de decomposição e ciclagem de nutrientes, pode-se dizer que a acumulação dos detritos orgânicos ao longo do tempo e a redução da ciclagem de nutrientes nos ambientes da planície de inundação do alto Rio Paraná são prováveis impactos dessa diminuição do fósforo, causada pelos reservatórios a montante.

Palavras-chave: respiração microbiana, ciclagem de nutrientes, planície de inundação, frações do sedimento, Rio Paraná.

\section{INTRODUCTION}

The sediments of waterbodies are composed of inorganic and organic fractions resulting from physical, chemical and biological activities (Ward et al., 1990). The sediment is intensively colonized by microorganisms, especially bacteria which aid in organic particle fragmentation (Lemke et al., 1995). The sediment compartment is essential for the nutrient budget of aquatic ecosystems, and can return nutrients to the productive zone of the water column during periods of mixing (Wetzel, 1981).

The organic matter present in sediments derives from depositional processes and is both autochthonous and allochthonous in origin (Lundsgaard \& Olesen, 1997). The different fractions of detritus are also chemically diverse, and their chemical composition is related to the origin of the sediment (Ward et al., 1990; Malcoln \& Stanley, 1982). Detritus originating from aquatic macrophytes and phytoplankton, for example, may be an important source of nitrogen and phosphorus for the sediment (Odum \& De La Cruz, 1967; Oláh et al., 1987; Tuominem et al., 1996).

The decrease in particle size and the changes in chemical characteristics of organic matter during decomposition are well known processes (Odum \& De La Cruz, 1967; Wetzel, 1981; Benner et al. 1988; Fuss \& Smock, 1996; Leff et al., 1997; Pagioro \& Thomaz, 1999). Some studies have demonstrated a consistent increase in microbial heterotrophic activity as detritus becomes smaller (Hargrave, 1972; Petersen et al., 1989). The nutritive value (e.g., organic matter content) of the sediment and the detritus may be an important predictor of microbial heterotrophic activity, as has been shown for bacteria (Findlay et al., 1986; Cole et al., 1988).

Tropical river floodplains support high biomasses of detritivorous invertebrates and fish, which have the sediment and associated organisms as an important food resource (Fugi et al., 1996;
Agostinho \& Zalewski, 1996). The high input of organic matter makes these environments highly heterotrophic (Rai \& Hill, 1984; Thomaz et al., 1997a).

In this study we focused on sediments in the upper Paraná River floodplain. We attempted to test i) whether the different sediment fractions differ according to selected chemical parameters, as indicators of its nutritive quality; and ii) whether there is a consistent pattern of heterotrophic microbial activity in relation to different fraction sizes and nutritive quality.

\section{STUDY AREA}

This study was carried out in six floodplain environments of the upper Paraná River: three lakes (Garças, Clara and Figueira), two backwaters of the Paraná River, and the main channel of the river (Fig. 1). All these environments are affected by the annual flood pulse of the Paraná River and intensive exchanges occur between them. Results of measurements of some limnological parameters in the environments are shown in Table 1. Further details of their limnological dynamics can be found in Thomaz et al. (1997a) and Pagioro et al. (1994, 1997).

Garças Lake is permanently connected to the Paraná River by a narrow (about $10 \mathrm{~m}$ wide) and long (about $100 \mathrm{~m}$ ) channel. The depth of the lake varies between 1.5 and $4.0 \mathrm{~m}$, depending on the flood stage of the river. Garças Lake can be considered a typical floodplain lake. Clara and Figueira Lakes are situated on Porto Rico Island. The great reduction in area (more than 50\%) and depth (from 3.0 to $0.5 \mathrm{~m}$ ) during the low water river stage makes these lakes almost temporary environments. The two backwaters are located on the shores of islands. Although their communication with the Paraná River is continual, they may be considered lentic environments except during high water periods. 


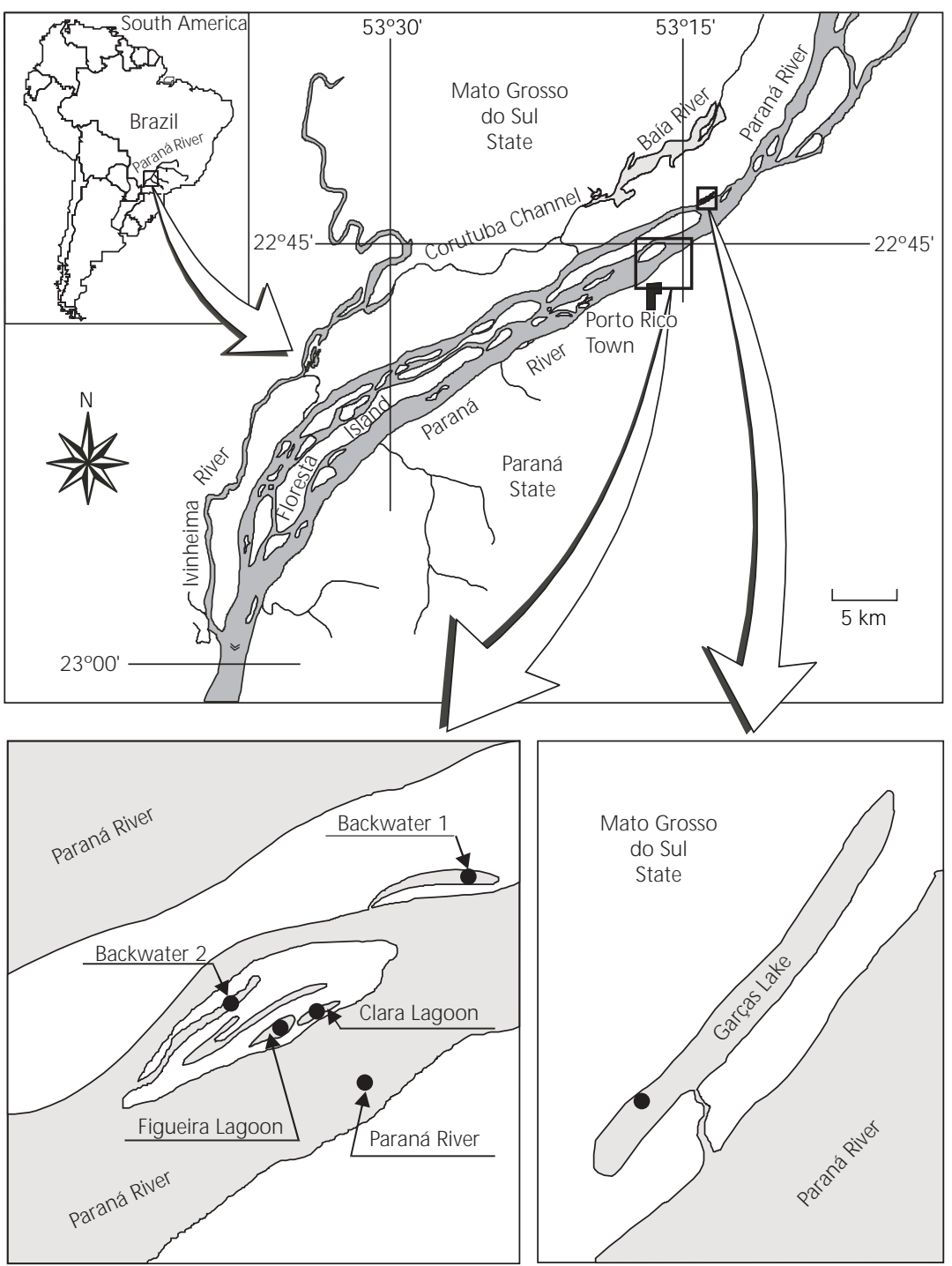

Fig. 1 - Location of the study site and sampling stations.

TABLE 1

Results of limnological parameters measured near the bottom sediment in the habitats analyzed in the floodplain immediately prior to sampling.

\begin{tabular}{|l|c|c|c|c|}
\hline & Temp. $\left({ }^{\mathbf{O}} \mathbf{C}\right)$ & $\mathbf{p H}$ & Cond. $(\boldsymbol{\mu S} \mathbf{S} / \mathbf{c m})$ & Oxygen $(\mathbf{m g} / \mathbf{L})$ \\
\hline Garças Lake & 25.4 & 7.10 & 45.0 & 5.15 \\
\hline Figueira Lake & 26.1 & 6.34 & 44.0 & 8.56 \\
\hline Clara Lake & 28.8 & 6.38 & 38.1 & 6.89 \\
\hline Backwater 1 & 25.5 & 7.20 & 50.0 & 7.18 \\
\hline Backwater 2 & 25.7 & 6.22 & 45.8 & 6.69 \\
\hline Paraná River & 26.3 & 6.40 & 36.0 & 8.74 \\
\hline
\end{tabular}


The sampling station in the Paraná River was situated in a stretch where the main channel is about $800 \mathrm{~m}$ wide and the depth about $5.0 \mathrm{~m}$ during low water.

Except for the main channel of the Paraná River, the littoral region of all environments are extensively colonized by aquatic macrophytes, especially Eichhornia azurea. The floating macrophytes Eichhornia crassipes, Pistia stratiotes, Salvinia auriculata, and several emergent species of Polygonum, Panicum, and Cyperaceae are also abundant (Souza et al., 1997; Agostinho et al., 1999).

\section{MATERIAL AND METHODS}

\section{Sampling and sediment treatment}

Sampling was carried out during the low water period (July-September 1997). Water samples were collected near the sediment, and the values of $\mathrm{pH}$, electrical conductivity (portable apparatus), temperature (thermistor), and dissolved oxygen (Winkler titration) were determined.

In each environment, to have enough material, collections of sediment were made close to the littoral zone, using a corer with transparent tubes. All material was collected in the morning and in less than one hour, to minimize errors associated with the diel cycle. The use of transparent tubes allowed us to separate the top $5 \mathrm{~cm}$ (recent sediment), the only layer that was used in our analyses. The collections were combined in order to have a sufficient quantity of sediment for analysis. The sediment was treated in the laboratory within 2 hours after sampling.

Fractionation was done using different mesh size, washing the sediment with water collected from each environment. The following fractions were considered: ultra-fine particles $(<70 \mu \mathrm{m})$, fine particles $(70-300 \mu \mathrm{m})$, medium particles (300$1,000 \mu \mathrm{m})$ and coarse particles $(>1,000 \mu \mathrm{m})$. This size classification follows that proposed by Petersen et al. (1989) for organic matter, with minor modifications. Petersen et al. (1989) used the following classification: ultra-fine particles $(0.5-75 \mu \mathrm{m})$, fine particles $(75-250 \mu \mathrm{m})$, medium particles (250$1,000 \mu \mathrm{m})$ and coarse particles $(>1,000 \mu \mathrm{m})$. Larger organisms (benthic fauna such as the Chironomidae) occasionally present in the coarse fraction were removed before beginning the incubations.

\section{Determination of microbial respiration}

Microbial respiration was measured by oxygen consumption in the dark. After fractionation, approximately $1.0 \mathrm{~g}$ fresh weight of each sediment fraction was transferred to $400 \mathrm{ml}$ polyethylene vessels with water collected from the respective environment. Before use, this water was aerated for one hour, in order that all treatments would have similar initial oxygen concentrations (near $100 \%$ saturation). The vessels (3 of each sediment fraction; total $=12$ ) were incubated at $25^{\circ} \mathrm{C}$ for four hours in the dark. A previous experiment showed that this time is within the range of maximum oxygen consumption by the sediment microbiota. Controls were incubated in the same way, but with no sediment. Studies carried out in lentic and lotic water bodies of the floodplain showed that dissolved oxygen are always close to saturation (80\%-100\%) all day long during the low water period (Thomaz et al., 1992; Pagioro et al., 1997). High concentrations of oxygen were also obtained during our samplings (see Table 1). Thus, oxygen concentrations in our incubations are close to the ones observed in situ.

Oxygen concentrations were determined by Winkler titration. Samples of each fresh sediment fraction size (about $1 \mathrm{~g} \mathrm{FW}$ ) were weighed, dried at $105^{\circ} \mathrm{C}$ during a day, until constant weight and reweighed to find the relationship fresh weight: dry weight. This relationship was used to transform the fresh to dry weight sediment. The results for microbial respiration were expressed in $\mathrm{mg} \mathrm{O}_{2}$ $\mathrm{gDW}^{-1} \mathrm{~h}^{-1}$.

\section{Carbon, nitrogen and phosphorus determination}

Samples of the sediment fractions were stored at $-20^{\circ} \mathrm{C}$. These samples were dried at $105^{\circ} \mathrm{C}$ and ground before chemical determinations. Carbon content was determined with a Shimadzu Total Organic Carbon Analyzer (model TOC-5000A) equipped with a Solid Sample Module (SSM5000A). Phosphorus and nitrogen concentrations were measured in a Micronal Spectrophotometer Model B382, by Flow Injection Analysis (Zagatto et al., 1981). For nitrogen determination the sediment samples were digested at $350^{\circ} \mathrm{C}$ with sulfuric acid. The ammonium resulting from the digestion was quantified by Bertholet's reaction (formation of indophenol blue) after addition of nitroprussate as a catalyst. Phosphorus concentrations were deter- 
mined by nitroperchloric digestion at $210^{\circ} \mathrm{C}$. The formation of acid phosphomolybdic follows ascorbic acid addition, with bismuth used as the catalyst.

\section{Data analysis}

Analysis of Variance (ANOVA) was used to compare the different fractions in relation to microbial respiration and carbon, nitrogen, and phosphorus concentrations. The data were square-root transformed to reduce discrepant values and to approximate to the normal distribution. For these comparisons, the environments were considered as replicates $(n=6)$. The significance levels were assessed by 5,000 randomization tests according to Manly (1991). The RT program was used for this test (Manly, 1991).

Multiple Regression Analysis was used to assess the effect of sediment chemical composition on microbial respiration. The microbial respiration data were log-transformed before analysis, to normalize the residuals.

\section{RESULTS}

A wide range of carbon, phosphorus and nitrogen concentrations was recorded in the fractions as well as in the environments analyzed. The fine, medium, and coarse fractions of the Paraná River sediment had, in general, lower carbon (< $0.1 \mathrm{ppm})$, nitrogen (185-898 ppm), and phosphorus concentrations (127-179 ppm) (Figs. 2a-2c). On the other hand, the concentrations of nitrogen and phosphorus in the ultra-fine sediment particles of the river approached those recorded for the other environments (Figs. 2a-2c). In the lakes and backwaters, carbon concentrations varied between 7,810 and 292,600 ppm, nitrogen between 1,037 and 9,280 ppm, and phosphorus between 124 and 1,193 ppm (Figs. 2a-2c).

The mean concentrations of carbon, nitrogen, and phosphorus, and microbial respiration in the different sediment fractions are shown in Table 2. Carbon was the only parameter that differed significantly among fractions $(\mathrm{F}=4.274, \mathrm{df}=3 ; 20, \mathrm{p}=$ 0.020). The carbon content of the ultra-fine particles was on average 9 times lower than the coarse particles. According to Duncan's test, the ultra-fine particles differed from the medium $(\mathrm{p}=0.049)$ and coarse $(\mathrm{p}=0.014)$ particles, and the fine particles differed from the coarse particles $(\mathrm{p}=0.015)$.
Considering that carbon comprises about $40 \%$ of organic matter (Wetzel \& Likens, 1991), the medium and coarse particles of all environments, except in the Paraná River, were highly organic (17\%-73\% organic matter).

Fine particles $(70-300 \mu \mathrm{m})$ had lower concentrations of nitrogen and phosphorus, but the sediment fractions did not differ significantly in relation to these nutrients $(\mathrm{F}=1.354, \mathrm{df}=3 ; 20$, $\mathrm{p}=0.285$, and $\mathrm{F}=1.318$, df $=3 ; 20, \mathrm{p}=0.293$, respectively).

Lower values for microbial respiration were recorded for the fine, medium and coarse particles of the Paraná River sediment $\left(<0.01 \mathrm{mgO}_{2}\right.$ $\mathrm{gDW}^{-1} \mathrm{~h}^{-1}$ ) (Fig. 3). The highest rates of microbial respiration were found in the ultra-fine sediment particles of the river $\left(1.38 \mathrm{mgO}_{2} \mathrm{gDW}^{-1} \mathrm{~h}^{-1}, \mathrm{SE}=\right.$ 0.659). Despite this tendency, the results of statistic analysis showed that the microbial respiration was not affected by particle size $(\mathrm{F}=1.268$, df $=3$; 20, $\mathrm{p}=0.313)$.

Multiple Regression Analysis showed that sediment carbon, nitrogen, and phosphorus concentrations explained $64 \%\left(\mathrm{r}^{2}\right.$ value) of the variability in microbial respiration.

The null hypothesis that all the partial coefficients were equal to zero was rejected $(\mathrm{F}=$ 7.0495; $\mathrm{p}=0.0022$ ).

Phosphorus concentration was the factor with the highest predictive capacity for microbial respiration (partial coefficient $=0.796, p=0.0039$, $\mathrm{n}=23$ ) (Fig. 4). The partial coefficients for carbon $(-0.210)$ and nitrogen $(0.108)$ were lower and nonsignificant.

According to the Multiple Regression Analysis, the microbial respiration can be modeled by the following equation:

Microbial Respiration $=-0.39-0.210 \mathrm{C}+0.108 \mathrm{~N}+$ $0.796 \mathrm{P}$

where microbial respiration is expressed in $\mathrm{mgO}_{2}$ $\mathrm{gDW}^{-1} \mathrm{~h}^{-1}$ and $\mathrm{C}, \mathrm{N}$ and $\mathrm{P}$ concentrations in ppm.

\section{DISCUSSION}

River sediment differs from lentic sediment mainly as a result of the hydrodynamics and sedimentation patterns. 

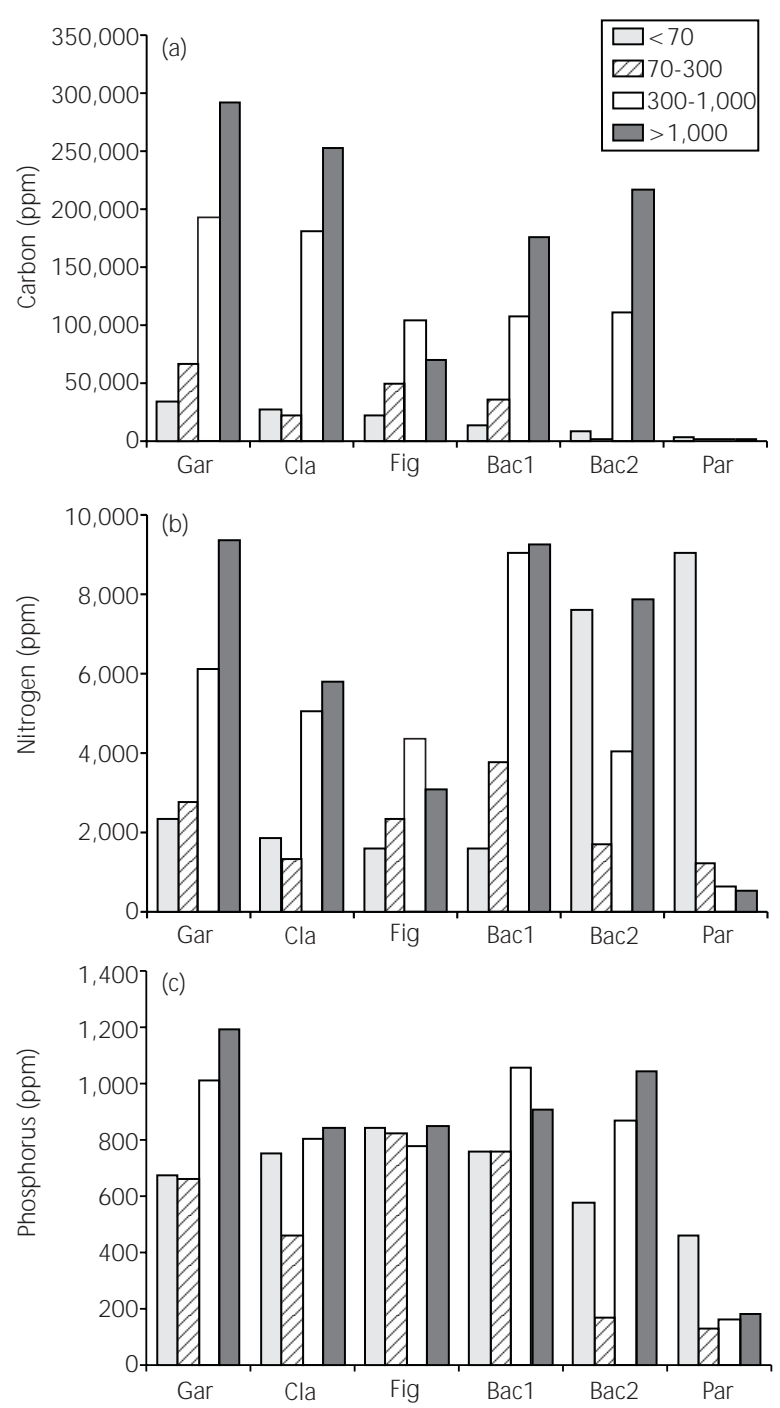

Fig. 2 - Nutrient content of the different-sized sediment particles in different habitats of the upper Paraná River floodplain. Gar, Cla and Fig = Garças, Clara and Figueira Lakes, respectively; Bac1 and Bac2 = Backwaters; Par = Paraná River.

TABLE 2

Mean ( $=6$ ) and standard deviation (in parentheses) of main nutrients (ppm) and microbial heterotrophic activity (microbial respiration in $\mathrm{mgO}_{2} \mathrm{gDW}^{-1} \mathrm{~h}^{-1}$ ).

\begin{tabular}{|l|c|c|c|c|}
\hline \multicolumn{1}{|c|}{ Particle size } & Carbon & Nitrogen & Phosphorus & Mic. resp. \\
\hline Ultra-fine & $18153(11800)$ & $3780(3501)$ & $660(143)$ & $0.297(0.183)^{*}$ \\
\hline Fine & $29153(26860)$ & $1915(1019)$ & $484(302)$ & $0.120(0.110)$ \\
\hline Medium & $116350(69162)$ & $4681(2837)$ & $763(314)$ & $0.286(0.220)$ \\
\hline Coarse & $167950(112374)^{\mathrm{a}}$ & $5818(3688)^{\mathrm{ac}}$ & $820(341)^{\mathrm{bc}}$ & $0.248(0.135)^{\mathrm{b}}$ \\
\hline
\end{tabular}

* The value of $1.38 \mathrm{mg} \mathrm{O}_{2} \mathrm{gDW}^{-1} \mathrm{~h}^{-1}$, found in the ultra-fine fraction of Paraná sediment, was excluded from the estimate. 


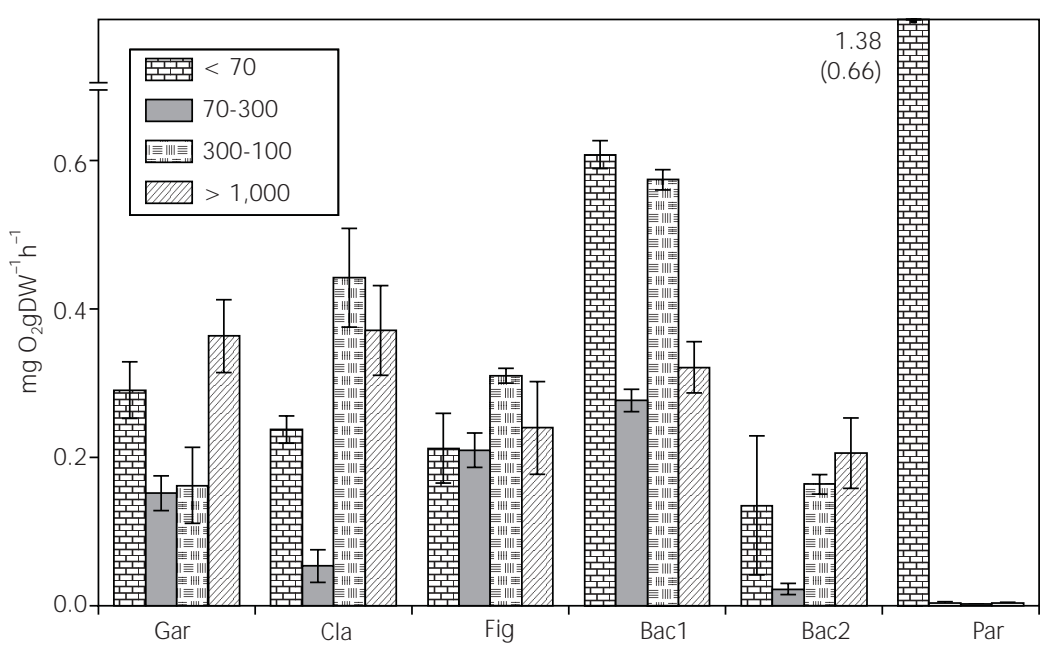

Fig. 3 - Microbial heterotrophic activity of the microbiota associated with different particle sizes in habitats of the upper Paraná River floodplain. Abbreviations are the same as Fig. 2. Note the outlier in the ultra-fine particle of the Paraná River (1.38 mg $\left.\mathrm{O}_{2} \mathrm{gDW}^{-1} \mathrm{~h}^{-1}\right)$. Mean of analytical replicates $+\mathrm{SE}(\mathrm{n}=3)$.

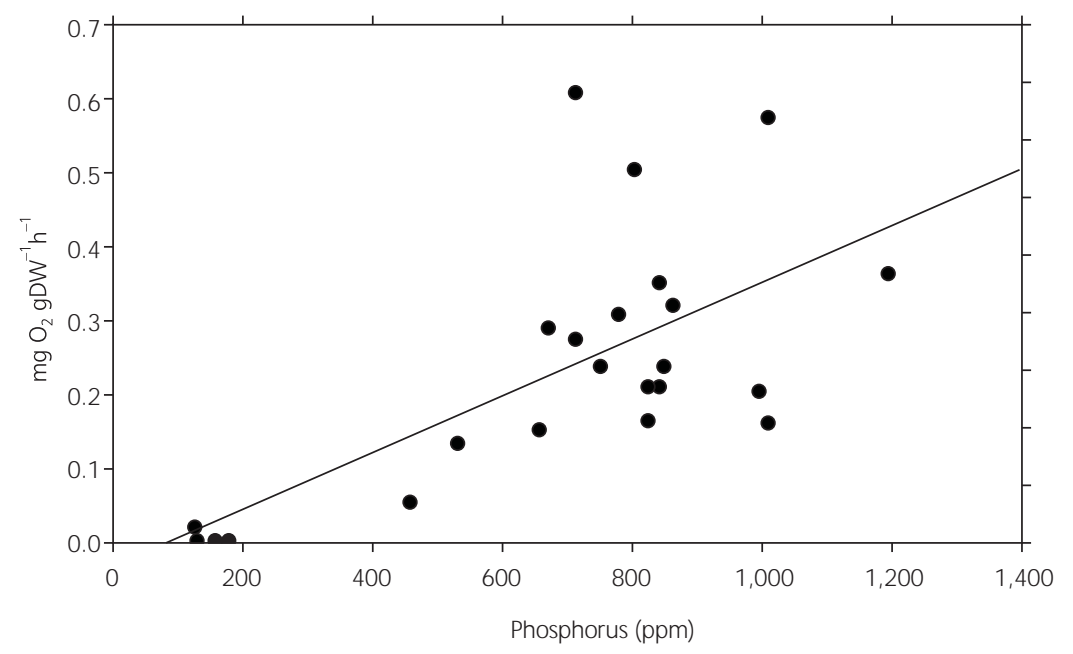

Fig. 4 - Correlation between microbial respiration and sediment phosphorus content. Different sediment size particles of six waterbodies were considered.

The sediment of the main channel of the Paraná River is composed mainly of medium sand (Takeda et al., 1997). According to our results, the larger fractions of the surface layer of this sediment are poor in carbon, nitrogen, and phosphorus compared to other lentic waterbodies and backwaters of its floodplain. These differences are also observed in the water column, since Paraná River water is lower in phosphorus and nitrogen than water in the floodplain lakes (Thomaz et al., 1997a).
The relatively high nutrient concentrations found in the sediments of the lentic environments may be associated with inputs of organic matter from the well-developed littoral zones, as well as from phytoplankton which is more abundant in these environments (Thomaz et al., 1997a; Train \& Rodrigues, 1998). Additions of autochthonous organic matter, such as phytoplankton (Tuominem et al., 1996) and aquatic macrophytes (Findlay et al., 1986), increase sediment microbial activity. 
These factors may account for the higher microbial respiration found, in general, in the sediments of the lentic waterbodies.

Conversely, the phosphorus and nitrogen concentrations in the ultra-fine particles of the Paraná River sediment approach the concentrations recorded in the other environments. Sedimentation of phosphorus with fine inorganic particles (e.g., silt) is a well-known process (Wetzel, 1981) and can account for such findings. The high nitrogen concentration of this fraction is more difficult to explain, given that the nitrogen dynamics of the sediments are poorly understood, but like phosphorus, adsorption on inorganic particles may be one of the reasons (Wetzel, 1981). Both nutrients may also be linked to the fine particulate organic matter, given that the ultra-fine sediment $(<70 \mu \mathrm{m})$ was the only fraction of the Paraná River where carbon was detectable (3,480 ppm).

Several investigations have shown that the nutritive quality of detritus in marine and freshwater environments increases with decreasing size of the detritus particles (Odum \& De La Cruz, 1967; Fuss \& Smock, 1996; Young \& Huryn, 1997), but others have not found such a relationship (Cammen, 1982). In our study, not only the organic matter but the bulk sediment was analyzed. The only significant tendency was observed for carbon content, which increased with sediment size. Differences in the origins of floodplain sediment may account for these differences. The larger sediment fractions were composed basically of detritus from leaves and branches of terrestrial and aquatic macrophytes, especially in the lentic waterbodies. On the other hand, the smaller fractions are composed basically of sand and silt, that is, are less organic. In contrast to carbon, the nitrogen and phosphorus contents were independent of sediment size.

The microbial activity of the sediment of the environments analyzed in the upper Paraná River floodplain was independent of particle size. Several investigators have found an inverse relationship between detritus size and oxygen consumption, a measure of microbial respiration (Hargrave, 1972; Petersen et al., 1989). The larger area-to-volume ratio of smaller particles, and hence the relatively larger available for microbial colonization, is one of the possible explanations of these results. In our experiment other factors seemed to be more important than particle size. In fact, irrespective of sediment size, the nutritional quality of the particles, in terms of carbon, nitrogen, and phosphorus, was well correlated with microbial respiration. Of the three nutrients, phosphorus seems to be the most important, given that the best relationship was obtained with this nutrient (partial coefficient $=0.796, p=0.0039)$. Although based on the $\mathrm{P}$ concentrations and $\mathrm{N}: \mathrm{P}$ ratios of the water, other studies of the floodplain lakes have also indicated that phosphorus is the principal nutrient that limits phytoplankton biomass and activity (Thomaz et al., 1997a; Paes da Silva \& Thomaz, 1997).

The correlation between phosphorus and microbial activity found in our work does not inherently imply a causative link. Nevertheless, we infer that phosphorus is limiting the microbial activity since several experimental investigations showed that phosphorus may be the principal limiting factor of the microbiota (Morris \& Lewis, 1992; Schweitzer \& Simon, 1995; Thomaz \& Esteves, 1998). The phosphorus limitation is common when the detritus are composed mainly by refractory material, i.e., in advanced stage of decomposition (Begon et al., 1996).

It has been widely emphasized that the impoundments located upstream of this section of the floodplain play an important role in phosphorus sedimentation, functioning as traps for this element (Tundisi et al., 1988; Agostinho et al., 1995, 1999). Reductions of ca. $36 \%-70 \%$ in the phosphorus content of water as it passes through a reservoir has been measured in several reservoirs of the Paraná basin (Thomaz et al., 1997b; Bini \& Pagioro, unpublished data). Assuming that such retention of phosphorus in the reservoirs causes a reduction of ca. $50 \%$ in the phosphorus concentrations of the floodplain water bodies, our regression analysis predicted that the microbial activity measured in the environments of the floodplain may be from $66 \%$ to $77 \%$ lower than it would be without such a reduction in phosphorus. Of course, these inference is valid for the phosphorus range found in our work and it still has to be considered with caution. Given the importance of phosphorus as stimulator of microbial activity, as suggested by our results, the reductions in phosphorus caused by the series of reservoirs are a cause for concern. These reductions may be causing decreases in the decomposition rates (i.e., accumulation of organic matter) and nutrient 
cycling in the floodplain environments, the consequences of which are still difficult to assess. More experiments under controlled conditions are necessary before reaching a final conclusion about phosphorus reduction effects.

Acknowledgments - We grateful to Dr. Luis Maurício Bini (UFG and PEA-UEM) for advice and suggestions regarding statistical treatments. Dra. Janet Reid (Smithsonian Institution, Washington, USA) revised the english. We also thank the technician Raul Ribeiro and the chemist Maria do Carmo Roberto (Laboratory of Limnology, Nupélia) for helping in the chemical analyses, and Alfredo Soares da Silva and Sebastião Rodrigues for field assistance. S. M. Thomaz is a CNPq Researcher and acknowledge a Grant received from this agency.

\section{REFERENCES}

AGOSTINHO, A. A., THOMAZ, S. M., MINTE-VERA, C. V. \& WINEMILLER, K. O., 1999, Biodiversity in the high Paraná River floodplain. In: B. Gopal (ed.), Wetlands Biodiversity. School of Environmental Sciences, Jawaharlal Nehru University, New Delhi (in press).

AGostinho, A. A., VAZZOLER, A. E. A. M. \& THOMAZ, S. M., 1995, The high Paraná basin: limnological and ichthyological aspects, pp. 59-103. In: J. G. Tundisi, C. E. Bicudo \& T. Matsumura-Tundisi (eds.), Limnology in Brazil. ABC/SBL, Rio de Janeiro.

AgOstinho, A. A. \& ZALEWSKI, M., 1996, A planície alagável do Rio Paraná: importância e preservação. Eduem, Maringá, 100p.

BEGON, M., HARPER, J. L. \& TOWSEND, C. R., 1996, Ecology: individuals, populations and communities. Blackwell, London, 1068p.

BENNER, R., LAY, J., K'NEES, E. \& HODSON, E., 1988, Carbon conversion efficiency for bacterial grouth on lignocellulose: Implications for detritus based food webs. Limnol. Oceanogr., 33: 1514-1526.

CAMMEN, L. M., 1982, Effect of particle size on organic content and microbial abundance within four marine sediments. Mar. Ecol. Prog. Ser., 9: 273-280.

COLE, J. J., FINDLAY, S. \& PACE, M. L., 1988, Bacterial production in fresh and saltwater ecosystems: a crosssystem overview. Mar. Ecol., 34: 1-10.

FINDLAY, S., SMITH, P. J. \& MEYER, J. L., 1986, Effect of detritus addition on metabolism of river sediment. Hydrobiologia, 137: 257-263.

FUGI, R., HAHN, N. S. \& AGOSTINHO, A. A., 1996, Feeding styles of five species of bottom-feeding fishes of high Paraná River. Environ. Biol. Fishes, 46(3): 297-307.

FUSS, C. \& SMOCK, L. A., 1996, Spatial and temporal variation of microbial respiration rates in a blackwater stream. Freshw. Biol., 36: 339-349.

HARGRAVE, B. T., 1972, Aerobic decomposition of sediment and detritus as a function of particle surface area and organic content. Limnol. Oceanogr., 17: 583-596.
LEFF, G. L., LEFF, A. A. \& LEMKE, M. J., 1997, Seasonal changes in planktonic bacterial assemblages of two Ohio streams. Freshw. Biol., 37: 129-134.

LEMKE, M. J., CHURCHILL, P. F. \& WETZEL, R. G., 1995, Effect of substrate and all surface hydropobicity on phosphate utilization in bacteria. Appl. Environ. Microbiol., 61: 913-919.

LUNDSGAARD, C. \& OLESEN, M., 1997, The origin of sedimenting detrital matter in a coastal system. Limnol. Oceanogr., 42(5): 1001-1005.

MALCOLN, S. J. \& STANLEY, S. O., 1982, The sediment environment, pp. 1-14. In: D. B. Nedwell \& C. M. Brown (eds.), Sediment Microbiology. Society for General Microbiology, London.

MANLY, B. F. J., 1991, Randomization and Monte Carlo methods in biology. Chapman and Hall, London, 281p.

MORRIS, D. P. \& LEWIS JR., W. M., 1992, Nutrient limitation of bacterioplankton growth in lake Dillon, Colorado. Limnol. Oceanogr., 37: 1179-1192.

ODUM, E. P. \& DE LA CRUZ, A. A., 1967, Detritus as a major component of ecosystems. Am. Inst. Biol. Sci., 13: 39-40.

OLÁH, J., SINHA, V. R. P., AYYAPPAN, S., PURUSHOTHAMAN, C. S. \& RADHEYSHYAM, S., 1987, Detritus associated respiration during macrophyte decomposition. Archiv. für. Hydrobiol., 111(2): 309-315.

PAES DA SILVA, L. \& THOMAZ, S. M., 1997, Diel variation of some limnological parameters and metabolism of a lagoon on the high Paraná River floodplain, MS. Proceedings of VIII Seminário Regional de Ecologia, 3: 169-189.

PAGIORO, T. A., ROBERTO, M. C. \& LANSAC-TÔHA, F. A., 1997, Comparative limnological analysis of two lagoons on the floodplain of the upper Paraná River, Brazil. Int. Jour. Ecol. Environ. Sci., 23: 229-239.

PAGIORO, T. A., ROBERTO, M. C., LANSAC-TÔHA, F. A. \& VERÍSSIMO, S., 1994, Caracterização limnológica de uma lagoa (Lagoa Figueira) da planície de inundação do alto Rio Paraná. Revista Unimar, 16(3): 203-215.

PAGIORO, T. A. \& THOMAZ, S. M., 1999, Decomposition of Eichhornia azurea from limnologically different environments of the upper Paraná River floodplain. Hydrobiologia, 411: 45-51.

PETERSEN, R. C. J., CUMMINS, K.W. \& WARD, G. M., 1989, Microbial and animal processing of detritus in a woodland stream. Ecol. Monogr., 59: 21-39.

RAI, H. \& HILL, G., 1984, Microbiology of Amazonian waters, pp. 413-441. In: H. Sioli (ed.), The Amazon: limnology and landscape ecology of a mighty tropical river and its basin. Dr. W. Junk, Dordrecht.

SOUZA, M. C., CISLINSKI, J. \& ROMAGNOLO, M. B., 1997, Levantamento florístico, pp. 343-368. In: A. E. A. M. Vazzoler, A. A. Agostinho \& N. S. Hahn (eds.), A planície de inundação do alto Rio Paraná. Eduem, Maringá.

SCHWEITZER, B. \& SIMON, M., 1995, Growth limitation of planktonic bacteria in a large mesotrophic lake. Microb. Ecol., 30: 89-104. 
TAKEDA, A. M., SHIMIDZY, G. Y. \& HIGUTI, J., 1997, Variação espaço-temporal da comunidade zoobêntica, pp. 157-177. In: A. E. A. M. Vazzoler, A. A. Agostinho \& N. S. Hahn (eds.), A planície de inundação do alto Rio Paraná. Eduem, Maringá.

THOMAZ, S. M., ROBERTO, M. C. \& BINI, L. M., 1997a, Fatores limnológicos e clorofila-a: caracterização dos habitats e influência do pulso de inundação, pp. 157-177. In: A. E. A. M. Vazzoler, A. A. Agostinho \& N. S. Hahn (eds.), A planície de inundação do alto Rio Paraná. Eduem, Maringá.

THOMAZ, S. M., ROBERTO, M. C. \& BINI, L. M., 1997b, Limnologia do reservatório de Segredo: padrões de variação espacial e temporal, pp. 19-37. In: A. A. Agostinho \& L. C. Gomes (eds.), Reservatório de Segredo: bases ecológicas para o manejo. Eduem, Maringá.

THOMAZ, S. M. \& ESTEVES, F. A., 1998, Bacterial dynamics in periphyton from different regions on a tropical coastal lagoon. Arch. Hydrobiol., 139: 495-507.

THOMAZ, S. M., ROBERTO, M. C., ESTEVES, F. A., LANSAC-TÔHA, F. A. \& LIMA, A. F., 1992, Influência do Regime hidrológico do Rio Paraná sobre os valores da transparência, oxigênio dissolvido e clorofila-a de três lagoas de várzea. Revista Unimar, 14: 153-162.

TRAIN, S. \& RODRIGUES, L. C., 1998, Temporal fluctuations of the phytoplankton community of the Baía River, in the upper Paraná River floodplain, Mato Grosso do Sul, Brazil. Hydrobiologia, 361: 125-134.
TUNDISI, J. G., MATSUMURA-TUNDISI, T., HENRY, R., ROCHA, O. \& HINO, K., 1988, Comparação do estado trófico de 23 reservatórios do Estado de São Paulo: eutrofização e manejo, pp. 165-204. In: J. G. Tundisi (ed.), Limnologia e manejo de represas. EESC/USP/ CHREA/ACIESP, São Carlos.

TUOMINEM, L., KAIRESALO, T., HARTIKAINEN, H. \& TALLBERG, P., 1996, Nutrient fluxes and microbial activity in sediment enriched with settled seston. Hydrobiologia, 335: 19-31.

WARD, G. M., WARD, A. K., DAHM, C. N. \& AUMEN, N. G., 1990, Origin and formation of organic particles in aquatic systems, pp. 27-56. In: R. S. Wotton (ed.), The biology of particles in aquatic systems. CRC Press, Boston.

WETZEL, R. G., 1981, Limnología. Omega S. A., Barcelona, $679 \mathrm{p}$.

WETZEL, R. G. \& LIKENS, G. L., 1991, Limnological analyses. Springer-Verlag, New York, 391p.

YOUNG, R. G. \& HURYN, A. D., 1997, Longitudinal patterns of organic matter transport and turnover along a New Zealand grassland river. Freshw. Biol., 38: 93-107.

ZAGATTO, E. A. G., JACINTO, A. O., REIS, B. F., KRUG, F. J., BERGAMIN, H., PESSENDA, L. C. R., MORTATTI, J. \& GINÉ, M. F., 1981, Manual de análise de plantas e águas empregando sistemas de injeção em fluxo. Universidade de São Paulo, Piracicaba. 